\title{
INDICATORS OF MARKERS OF BONE METABOLISM IN PATIENTS WITH GENERALIZED PERIODONTITIS DEPENDING ON BLOOD GROUP
}

\author{
Yurii BANDRIVSKY1凶, Orysia BANDRIVSKA ${ }^{2}$, Romam GNID $^{3}$, Lidia MINKO${ }^{3}$, \\ Maryana SHEVCHUK ${ }^{3}$ \\ ${ }^{1}$ „I. Horbachevsky“ Ternopil State Medical University, Department of Child Dentistry, Ternopil, Ukraine \\ ${ }^{2}$ „I. Horbachevsky“ Ternopil State Medical University Department of Orthopedic Dentistry, Ternopil, \\ Ukraine \\ ${ }^{3}$ „Danylo Halytsky“ Lviv National Medical University, Department of Therapeutic Dentistry FPGE, Lviv, \\ Ukraine
}

Received 2 Dec 2018, corrections received 3 Jan 2019, Accepted 27 Jan 2019

https://doi.org/10.31688/ABMU.2019.54.1.10

\section{Abstract}

Introduction. The close relationship of the osteoporosis with the periodontal tissue disease is of great importance in dentistry, because of the development of inflammatory-destructive processes of tooth holding tissues. A database to individualize the basics of metabolism in terms of bone remodeling in patients with generalized periodontitis (GP) in connection with ABO-belonging will reveal the fundamental basis of the influence of group-specific features of blood flow and treatment of generalized periodontitis.

The aim of the study was to assess the dynamics of bone remodeling markers in blood and oral liquid of patients with generalized periodontitis, with different blood groups.

Material and methods. The clinical and laboratory studies were conducted in 175 patients with generalized periodontitis (main group) and in 120 persons without somatic and dental diseases (comparison group), who were divided into groups in connection

\section{Résumé}

Indicateurs des marqueurs du métabolisme osseux chez des patients présentant une périodontite généralisée d'après l'appartenance à un groupe sanguin

Introduction. La stomatologie revêt une grande importance pour ce qui est de la relation entre l'ostéoporose et la maladie des tissus parodontaux, considérée comme un facteur de risque du développement des processus inflammatoires destructeurs des tissus qui fixent les dents. L'absence d'une base de données permettant d'individualiser le métabolisme primaire dans les paramètres de remodelage osseux chez les patients atteints de parodontite généralisée (GP) en lien avec l'appartenance à $\mathrm{AB}$, révélera la base fondamentale de l'influence des caractéristiques de la circulation sanguine et du traitement de la parodontite généralisée.

Le but de l'étude était la dynamique des marqueurs de remodelage osseux dans le sang et le liquide buccal 
with $\mathrm{AB}$-belonging. It was determined the activity of acid and alkaline phosphatase in blood and oral liquid of patients, by conventional biochemical methods, and levels of osteocalcin and C-end telopeptide by ELISA. Results. Patients with generalized periodontitis presented a significant increase of the markers of bone resorption (acid phosphatase and C-end telopeptides), while healthy persons presented a reduction of these parameters of bone formation (osteocalcin and alkaline phosphatase) in blood and oral liquid, regardless of blood group affiliation. Further, processes of bone resorption in blood and oral liquid were examined in patients with GP, carriers of O(I) and A(II) blood groups. It was noted that the process of bone formation for these levels of osteocalcin and alkaline phosphatase were significantly lower in patients with GP, in $\mathrm{O}(\mathrm{I})$ and $\mathrm{B}(\mathrm{III})$ blood groups.

Conclusions. The results of the study showed that in patients with GP there is an imbalance in the processes of bone remodeling, regardless of $\mathrm{ABO}$-belonging. The study of the composition and functions, not only of blood, but also of saliva, can find high regulatory and trophic potential of this biological environment and the diversity of its protective and compensatory features.

Keywords: generalized periodontitis, $\mathrm{AB} 0$-belonging, bone tissue, markers of bone metabolism.

\author{
Abbreviations \\ $\mathrm{GP}=$ generalized periodontitis \\ TRACP $=$ acid phosphatase tartrate \\ BSALP $=$ alkaline phosphatase \\ $\mathrm{P} 1 \mathrm{CP}=\mathrm{C}$-terminal telopeptides \\ $\mathrm{OC}=$ osteocalcin
}

\section{INTRODUCTION}

One of the main problems of modern dentistry are periodontal tissue diseases, because of their significant prevalence among people of different ages, the lack of pre nosological diagnostic methods and effective methods of prevention and treatment ${ }^{1-4}$. Generalized periodontal diseases are characterized by the progression of the inflammatory-destructive processes, which with age leads to the complete destruction of the tooth-holding apparatus and the premature loss of teeth ${ }^{5-8}$. As a result of impaired bone metabolism of the alveolar process, its resorption is accelerated, which is caused by the action of both local regulatory and systemic causes ${ }^{3,9,10}$. Recent studies underlined the relationship of osteoporosis with des patients atteints de parodontite généralisée avec une affiliation différente au groupe sanguin.

Méthodes. Les études cliniques et de laboratoire ont été menées chez 175 patients atteints de parodontite généralisée (groupe principal) et chez 120 personnes sans maladies somatiques ou dentaires (groupe témoin), divisées en groupes liés à l'appartenance à ABO. L'activité de la phosphatase acide et alcaline dans le sang et le liquide buccal des patients a été déterminée par des méthodes biochimiques classiques et par les taux d'ostéocalcine et de télopeptide C-end par ELISA.

Les résultats. Il est établi que, chez les patients atteints de parodontite généralisée, on a examiné une augmentation significative des valeurs des marqueurs de la résorption osseuse (phosphatase acide et télopeptides C-end) dans le contexte de la réduction de ces paramètres de formation liés aux valeurs chez les personnes en bonne santé, quelle que soit leur appartenance à un groupe sanguin. Ainsi, des processus plus importants de résorption osseuse dans le sang et le liquide buccal ont été examinés chez des patients atteints de GP, de porteurs de groupes de sang $\mathrm{O}$ (I) et A (II). Ainsi, il est à noter que le processus de formation osseuse de ces taux d'ostéocalcine et de phosphatase alcaline était significativement plus faible chez les patients atteints de GP, porteurs de groupes de sang $\mathrm{O}$ (I) et $\mathrm{B}(\mathrm{III})$.

Conclusions. Les résultats des études menées ont montré que les processus de remodelage osseux sont déséquilibrés chez les patients atteints de GP, indépendamment de leur appartenance à ABO. L'étude de la composition et des fonctions du sang, mais aussi de la salive, permet de mettre en évidence un potentiel régulateur et trophique élevé pour cet environnement biologique et la diversité de ses caractéristiques protectrices et compensatrices.

Mots-clés: parodontite généralisée, appartenance $\mathrm{ABO}$, tissu osseux, marqueurs du métabolisme osseux.

periodontal disease and consider it as a risk factor for the occurrence of periodontal disease. Age-related bone tissue repair, a violation of bone metabolism, accelerates the resorption of the alveolar process, causing the deterioration of the flow of generalized periodontitis $(\mathrm{GP})^{11-13}$.

At the same time, there is practically no database for the individualization of the molecular basis of metabolism in some parameters, one of which is blood group genetically determined ${ }^{14}$. The study of bone remodeling data in patients with generalized periodontitis, in connection with $\mathrm{AB} 0$-affiliation, would increase the effectiveness of evaluating the results of bone metabolism markers, for a new approach, in connection with the influence of group-specific blood on the course of generalized periodontitis ${ }^{15-17}$. 
In the literature, there is interest for the composition and functions not only of the blood, but also of oral fluid, in order to reveal the high regulatory and trophic potential of this biological environment and the diversity of its protective and compensatory properties $^{18-20}$.

The OBJective OF THE STUDY was to evaluate the $d y$ namics of markers of bone metabolism in the blood and oral fluid, in patients with generalized periodontitis, with different blood groups.

\section{Materials AND Methods}

Clinical and laboratory studies were conducted in 175 patients with generalized periodontitis of grade I - $\mathrm{III}^{6}$, aged 20 to 55 years, male, whose average age was $45.9 \pm 3.4$ years (main group). The diagnosis of periodontal tissues was established on the basis of history, dental and periodontal examination, according to standard indicators ${ }^{2}$. Of the study group, 50 patients $(28.57 \%)$ were carriers of the $\mathrm{O}$ (I) group, 42 people $(24.0 \%)$ were representatives of the A (II) group, 40 patients (22.86\%) - B (III) groups and 43 (24.57\%) with AB (IV) blood group ${ }^{21}$. The control group consisted of 120 people without somatic and dental diseases, with identical blood group.

To determine the alterations of systemic bone metabolism, we studied the activity of resistant acid phosphatase tartrate (TRACP), alkaline phosphatase (BSALP), C-terminal telopeptides (P1CP) and osteocalcin (OC) in the blood and oral fluid of patients with generalized periodontitis ${ }^{22,23} .5 \mathrm{~mL}$ of blood from the ulnar vein have been obtained by venipuncture into the vacuum system for blood sampling, for hematological studies, in compliance with all standard pre-analytical procedures ${ }^{24}$. The intake of oral fluid from the studied contingent was carried out in the morning hours, by spitting into sterile measuring tubes. The resulting samples were carefully mixed and centrifuged for 5 minutes at 3,000 rpm, until a clear supernatant was formed ${ }^{18}$.

The TRACP activity in biological fluids was determined according to the modified Hillman reaction. The alkaline phosphatase activity was assessed by hydrolysis of $\beta$-glycerophosphate using Lachema reagents. C-terminal telopeptides and osteocalcin were determined by enzyme immunoassay, using the N-MID-osteocalcin and Cross Laps ${ }^{\mathrm{TM}}$ ELISA test systems from Nordic Bioscience Diagnostics $\mathrm{A} / \mathrm{S}^{9,12}$. The obtained results were processed statistically using the software packages „Statgraphics“ and „Statistica 6.0“.

\section{Results}

We have found that the serum activity of TRACP-lysosomal enzyme, which hydrolyzes phosphoric monoesters in an acidic environment ${ }^{11,25}$, in practically healthy individuals of the control group, was on average $36.68 \%$ lower than in patients with generalized periodontitis $(3.19 \pm 0.09 \mathrm{ng} / \mathrm{mL}$ versus $4.36 \pm 0.09 \mathrm{ng} / \mathrm{mL}$, respectively, $\mathrm{p}<0.01)$. It was noted that in patients with GP, the TRACP activity in the serum increased significantly, regardless of the blood group (Fig. 1). In the same time, the maximum increase in the analysed parameter was determined for carriers A(II) - by $48.15 \%$ and $O$ (I) - by $39.10 \%$ of blood groups with GP, $p<0.01$. Among the representatives of $\mathrm{AB}$ (IV) and $\mathrm{B}$ (III) blood groups with $\mathrm{SE}$, the increase in TRACP activity was slightly lower - by $33.33 \%$ and by $27.78 \%$, respectively, in comparison with the values in the control group, with identical blood group, $\mathrm{p}<0.01$.

Carbox-terminal (C-terminal telopeptides of human collagen type 1 (P1CP) are the most informative markers of bone resorption ${ }^{12,26}$. It was established that in the control group, the blood serum level of P1CP was lower by $56.80 \%$ compared to similar data in patients with SE $(0.125 \pm 0.03 \mathrm{ng} / \mathrm{mL}$ versus $0.196 \pm 0.03$ $\mathrm{ng} / \mathrm{mL}, \mathrm{p}<0.05$. A significant increase in the analysed parameter in serum was determined in patients with SE, regardless of the blood group: by $76.03 \%$ in A(II) carriers, by $54.62 \%$ in B(III), by $49.24 \%$ in O(I) and by $46.51 \%$ in $\mathrm{AB}(\mathrm{IV})$ blood groups, $\mathrm{p}<0.05$.

Osteocalcin (OC), synthesized by osteoblasts, is considered one of the most informative biochemical markers of bone tissue formation ${ }^{2,27}$, and its blood serum level correlates with the process of bone formation. It was determined that in practically healthy individuals, the level of serum OC was, on average, $22.95 \%$ higher than in patients with GP $(13.77 \pm 0.73 \mathrm{ng} / \mathrm{mL}$ versus $10.61 \pm 0.72 \mathrm{ng} / \mathrm{mL}$, respectively, $\mathrm{p}<0.01$ ). It was noted that in patients of the main group, regardless of blood group, the OC content in serum decreased approximately equally (by $23.0 \%$, on average), and differed in statistical significance from the corresponding data in the control group $(\mathrm{p}<0.01, \mathrm{p}<0.05)$.

The activity of bone enzyme alkaline phosphatase, whose dynamics is of great importance for the characterization of bone mineral density $3,5,28$, in the control group was $30.66 \%$ higher compared to study group $(24.72 \pm 1.69 \mathrm{ng} / \mathrm{mL}$ vs $17.14 \pm 1.68 \mathrm{ng} /$ $\mathrm{mL}, \mathrm{p}<0.01$ ). In carriers of $\mathrm{O}(\mathrm{I})$ and $\mathrm{A}(\mathrm{II})$ blood groups with generalized periodontitis, the maximum decrease in the analysed indicator was observed: by $33.10 \%$ and by $32.30 \%$, respectively, $p<0.01$. The decrease in the values of the analysed parameter in representatives of $\mathrm{AB}(\mathrm{IV})$ and $\mathrm{B}(\mathrm{III})$ blood groups with 


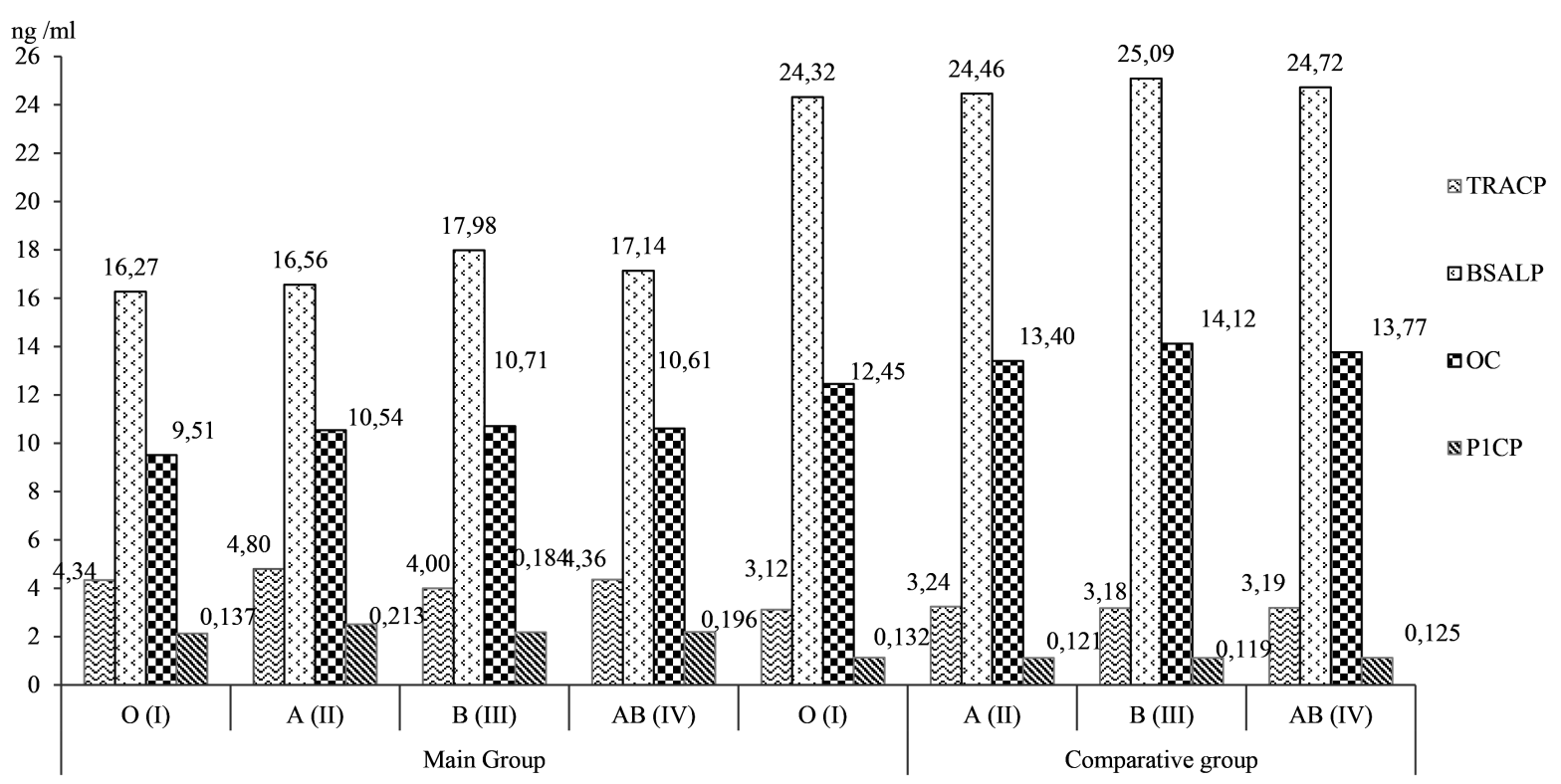

Figure 1. Dynamics of bone metabolism markers depending on blood group.

GP was: by $29.02 \%, \mathrm{p}<0.01$, and by $28.34 \%$, $\mathrm{p}<0.05$, respectively.

The activity of TRACP in the oral fluid of patients with GP was, on average, 23.02\% higher than in practically healthy individuals $(3.42 \pm 0.05 \mathrm{ng} / \mathrm{mL}$ versus $2.78 \pm 0.07 \mathrm{ng} / \mathrm{mL}, \mathrm{p}<0.01)$. The maximum increase in the activity of TRACP in the oral fluid was determined in carriers of $\mathrm{O}(\mathrm{I})$ and $\mathrm{AB}(\mathrm{IV})$ blood groups with generalized periodontitis - by $26.47 \%$ and $23.57 \%$, respectively, $\mathrm{p}<0.01$. In representatives of A(II) and B(III) blood groups with GP (Fig. 2), the activity of the values of the analysed parameter increased by $22.55 \%$ and $20.49 \%$, respectively, but differed in statistical significance from data in practically healthy people, $\mathrm{p}<0.01$.

The content of $\mathrm{P} 1 \mathrm{CP}$ in the oral fluid of patients with GP was, on average, 3.4 times higher than in the comparison group $(0.44 \pm 0.01 \mathrm{ng} /$ $\mathrm{ml}$ versus $0.13 \pm 0.02 \mathrm{ng} / \mathrm{mL}, \mathrm{p}<0.01)$. The maximum increase in the level of $\mathrm{P} 1 \mathrm{CP}$ in the oral fluid was observed in carriers of $\mathrm{O}(\mathrm{I})$ and $\mathrm{B}(\mathrm{III})$ blood groups with GP, by 4.0 and 3.8 times, respectively, $\mathrm{p}<0.01$. Representatives of the A(II) and AB(IV) blood groups of the main group showed that the increase in the values of this parameter was slightly smaller (3.0 and 2.7 times, respectively), but differed in statistical significance from the data in the control group, $\mathrm{p}<0.01$.

The BSALP activity in the oral fluid of the control group was with $18.89 \%$ higher than the mean values in patients of the study group $(2.85 \pm 0.07 \mathrm{ng} / \mathrm{mL}$ versus $2.31 \pm 0.06 \mathrm{ng} / \mathrm{mL}$, respectively, $\mathrm{p}<0.01)$. The maximum and the same decrease in BSALP activity in the oral fluid was noted in representatives of B(III) and $\mathrm{AB}(\mathrm{IV})$ blood groups with GP - by $19.68 \%$, p $<0.01$. Slightly less, but in the same percentage values $(18.10 \%)$, the BSALP activity in the oral fluid in the $\mathrm{O}(\mathrm{I})$ and $\mathrm{A}(\mathrm{II})$ carriers decreased in generalized periodontitis blood groups, $\mathrm{p}<0.01$.

The level of osteocalcin in the oral fluid of patients with GP was, on average, with $47.57 \%$ less than the corresponding data in the comparative group $(0.54 \pm 0.05 \mathrm{ng} / \mathrm{mL}$ versus $1.03 \pm 0.07 \mathrm{ng} / \mathrm{mL}$, $\mathrm{p}<0.01$ ). The maximum decrease in OC was recorded in patients with GP with $\mathrm{O}$ (I) blood group (by $51.02 \%, \mathrm{p}<0.01$ ), with the minimum decrease of this parameter in representatives of $\mathrm{A}(\mathrm{II})$ blood group - by $44.44 \%, \mathrm{p}<0.01$. The values of OC in the oral fluid of patients with GP, carriers of B(III) and $\mathrm{AB}(\mathrm{IV})$ blood groups, decreased almost identically with the control group with identical blood group (by $47.74 \%$, p <0.01).

\section{Discussion}

Representatives of $\mathrm{O}(\mathrm{I})$ and $\mathrm{A}(\mathrm{II})$ blood groups had acid phosphatase activity and C-terminal telopeptide levels in serum and oral fluid, as well as bone resorption processes, more significant compared to patients with GP, carriers of B(III) and AB(IV) blood groups. Also, it was noted that the process of formation of bone tissue, regarding osteocalcin and alkaline phosphatase activity in biological fluids, in patients with GP, carriers of O(I) and B(III) blood groups, was significantly reduced. 


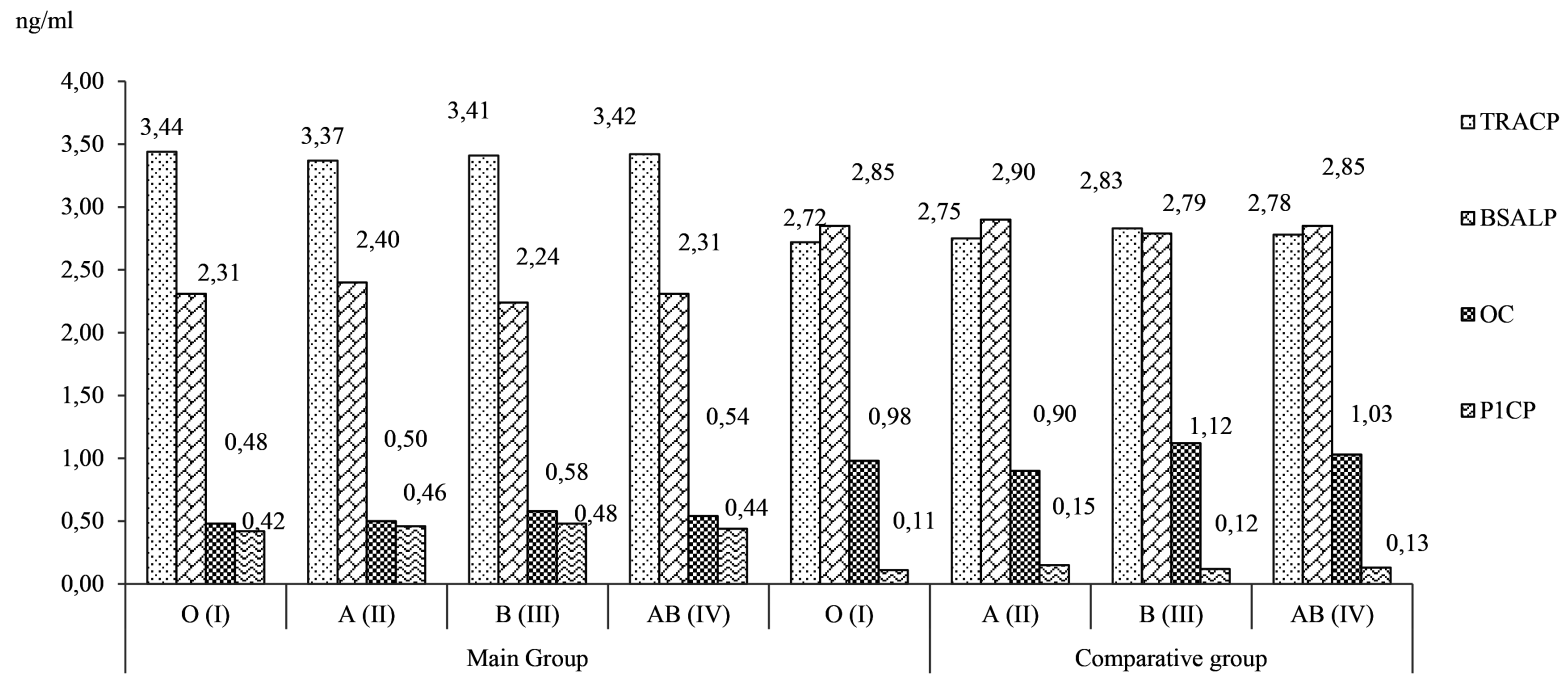

Figure 2. Dynamics of markers of bone metabolism in the oral fluid in patients of study groups depending on the blood group.

\section{Conclusions}

The analysis of the values of bone remodeling markers in patients with GP found a significant imbalance in the processes of formation and resorption of bone tissue compared with the data in practically healthy individuals, regardless of the blood group.

\section{Compliance with Ethics Requirements:}

„The authors declare no conflict of interest regarding this article"

"The authors declare that all the procedures and experiments of this study respect the ethical standards in the Helsinki Declaration of 1975, as revised in 2008(5), as well as the national law."

\section{References}

1. Abolmasov NN. Strategiya i taktika zabolevaniy parodonta. Stomatologiya. 2003;(4): 34-39. [in Russian].

2. Grigorian AS, Grudyanov AI, Ryabukhina NA, Frolova OA. Bolezni parodonta. Patogenez, dlagnostika, lecheniye. Moscow: MIA. 2004: 287.

3. Bandrivsky YL, Vynogradova OM, Minko LY Modern aspects of etiopathogenesis of periodontal disease. European International Journal of Science and Technology. 2017; (1): 44-50.

4. Petersen P. E. The global burden of oral diseases and risk to oral health. Bull. World Health Organ. 2015;83(9):661-669.

5. Bandrivska NN, Bandrivsky YL. Clinical morphology symptomatics of inflammatory parodontal diseases. Ukrainskyi medychnyi almanakh. 2009;(5):19-21 [in Ukrainian].

6. Borysenko AV. Therapeutic stomatology. Kyiv, Medytsyna, 2008; 2:409.

7. Offenbacher S. Periodontal diseases pathogenesis. Amer Periodontol. 2013;1: 821-878.
8. Shiau HJ, Reynolds MA. Sex differences in destructive periodontal disease: a systematic review. J Periodontol. 2010;81(10):1379-1389.

9. Mazur IP, Povoroznyuk VV. Kostnaya sistema I zabolevaniya parodonta. Sovremennaya stomatologiya. 2000;(2):32-36 [in Ukrainian].

10. Stahl SS. Host resistance and periodontal diseases. J Dent Res. 2010;49(2):248-255.

11. Sones FD, Walinsby JE. Osteoporosis and mandibular bone resorption a prosthodontic perspective. J Prosthet Dent. 2016;6:732-736.

12. Tomaszewski T. Assessment of mandible bone structure in patients with generic osteoporosis symptoms. Annales Universitatis Mariae Curie-Sklodowska. 2012;57: 329-341.

13. Fourel J. Periodontosis: a periodontal syndrome. J Periodontol. 1972;43:240-255.

14. Haffajee AD, Socransky SS. Microbial etiological agents of destructive periodontal diseases. Periodontology. 1994; 5:78-111.

15. Bennet E, Steffensen R, Clausen H, et al. Genomic cloning of the human histo-blood group ABO locus. Biochem Biophys Res Commun. 1995; 206:318-325.

16. Jee WS. Principles in bone physiology. J Musculoskelet Neuronal Interact 2000; 1:11-13.

17. Isacov I, Levco S. Preoperative assessment of patients with inflammatory processes in the maxillo-facial region: a minireview. Arch Balk Med Union. 2018;53(2): 275-280.

18. Nomura Y, Tanaki Y, Tanaka T. Screening of periodontitis with salivary enzyme test. J Oral Sral Sci. 2006; 12:177-183.

19. Schenkel-Bruner H. Human blood groups. Chemical and biochemical basis of antigen specificity. New York, 2000, 30-293.

20. Young MF. Bone matrix proteins: further function, regulation, and relationship to osteoporosis. Osteoporosis Int. 2003; 14: S35-S42.

21. Yamamoto, F. Molecular genetic of the ABO histo-blood group system. Vox Sang. 1995;69:1-7.

22. Neil DA, Reid ME. The Rh blood group system: a review. Blood. 2000;15:375-387.

23. Mitchell B, Cole S, Bauer R, et al. Genes influencing variation in serum osteocalcin concentrations are linked to 
markers on chromosomes 16q and 20ql. The Journal of Clinical Endocrinology \&O Metabolism. 2002; 85(4):1362-1366.

24. Daniels GL, Anstee DJ, Carton JP, et al. Blood groups clas sification. Vox Sang. 1995; 69(4): 265-279.

25. Manolagas SC, Jilka RL. Bone marrow, cytokines, and bone remodeling. Emerging insights into the pathophysiology of osteoporosis. N Engl J Med. 1995;332(5):305-311.
26. Chen DZM, Mundy GR. Bone morphogenetic proteins. Growth Fact. 2014;22:233-241.

27. Duncan E, Cardon L, Sinsheimer J, et al. Site and gender specificity of inheritance of bone mineral density. J Bone Miner Res. 2003;18(8):1531.

28. Schaffer M. Teeth in the line of mandibular fractures : epidemiology, management and complications. Revista de Cirurgia e Traumatologia Bucco-maxillo-facial. 2013;13(2): 23-30. 